\title{
REVIEW ESSAY
}

\section{Big Game and the State: The History of the Hunt in Canada Joanna Dean-Carleton University}

Serge Bouchard, Caribou Hunter: A Song of a Vanished Innu Life trans. Joan Irving (Montreal: Les Éditions Boréal, 2006).

J. Alexander Burnett, Passion for Wildlife: The History of the Canadian Wildlife Service (Vancouver: University of British Columbia Press, 2003).

Greg Gillespie, Hunting for Empire: Narratives of Sport in Rupert's Land, 1840-1870 (Vancouver: University of British Columbia Press, 2007).

Peter Kulchyski and Frank James Tester, Kiumajut (Talking Back): Game Management and Inuit Rights, 1900-70 (Vancouver: University of British Columbia Press, 2007).

When four books come out within twelve months on the subject of hunting and wildlife management in the Canadian north, one has to ask why. What is it about the hunting of caribou, or muskoxen, or bison that warrants such attention? There has been a steady stream of books on the subject in recent years-Tina Loo's States of Nature (2006), J. Alexander Burnett's A Passion for Wildlife (2003), Greg Colpitt's Game in the Garden (2002) and Lyle Dick's Muskox Land (2001) -and the stream shows no sign of abating. Hans M. Carlson's Home is the Hunter: The James Bay Cree and Their Land is in press, and there is much promising doctoral research on the topic. ${ }^{1}$ One reason for the number of books lies in the publishing energy at the University of British Columbia Press, which is responsible for all but one of the books listed above. In particular the new environmental history series, Nature/History/Society, edited by Graeme Wynn, has resulted in a remarkable lineup of innovative environmental histories. Another lies in the growing field of environmental history in Canada. More globally, the answer lies in the fertile intersection of cultural history and environmental history. The set of books published describe a contested, complex set of social interactions around wildlife management that bring environmental history into the mainstream; the histories of hunting engage in debates about imperial power, the liberal state, class, aboriginal rights and identity, and ethnicity. ${ }^{2}$

Janet Foster's Working for Wildlife, first published in 1978, with a second edition twenty years later, laid the groundwork for the history of wildlife conservation in Canada. ${ }^{3}$ Foster's is a celebratory account of enlightened federal bureaucrats. Her interpretation was informed by American debates about wilderness 
preservation, and is mainly concerned with identifying a made-in-Canada conservation movement. Burnett's A Passion for Wildlife is similar in approach. Burnett had been a writer with the Canadian Wildlife Service (CWS) for ten years when he was invited to write their fiftieth anniversary history and his sympathies lie with the CWS. He identifies closely with the members of the service, noting, "it would be impossible to describe the spirit and dedication of the enforcement officers in the field." He has little patience with the poacher, who "seems to have been motivated more by ignorance, self indulgence, and greed than by a malicious desire to profit from a life of crime." ${ }^{5}$ The value in Burnett's account lies in his interviews. He interviewed 120 employees; their voices come through clearly in the text, and sometimes undermine the interpretive thrust of the book. John Tener, for example, described his meeting with Harrison Lewis, chief of the CWS, in 1951 when he was a newly minted biologist:

Lewis could be quite an abrupt man. When I entered the office, he turned to me and said, "What do you know about muskoxen?" And I said, "Nothing, sir." And he said, "Neither does anyone else, so you're going to go and find out." And that's how I became the government mammalogist for the districts of Franklin and Keewatin, which basically meant the whole of the eastern Arctic mainland and the Arctic Archipelago. ${ }^{6}$

Tener's account reveals the heady confidence in science and prog ress that informed the Service as it stepped into a more interventionist role in the post World War II (WWII) expansion into the north. He was proud of his role as a pioneer, working along the frontiers of scientific knowledge. "When I started studying muskoxen, I was the only person doing it. Various explorers had written about the animals, but I was interested in doing a complete study: life history, ecology and so forth." Tener's muskox research, which became the basis for his doctoral thesis at Oxford, as well as his definitive Muskoxen in Canada (1965), is widely respected.

This confidence in science, however, takes on a different light in more recent accounts. In Kiumajut (Talking Back), Kulchyski and Tester acknowledge the honorable intentions of bureaucrats who were "some of the brightest, most committed and most passionate men and women Canada had to offer." describe men like Tener as instruments of high modernism, and their science as an exercise of Foucauldian "biopolitics." "Attempts by the state to know and manage wildlife, by knowing and managing hunters, can be thought of as an element of a broader turn by the state to the definition and management of 'life' as an integral element of its totalizing arsenal." ${ }^{\prime \prime}$ Similarly, in his meticulous examination of wildlife policy in the north, Hunters at the Margin (reviewed elsewhere in this issue), John Sandlos concludes: "the institution of wildlife conservation and its attendant instruments constituted a deliberate imposition of state power over independent Aboriginal communities in northern Canada." Their analysis follows upon Tina 
Loo's groundbreaking history of wildlife conservation, States of Nature, (also reviewed elsewhere in this issue) and makes us rethink John Tener's words. His science was not innocent; nor was his vast empire an empty one. Wildlife biology displaced traditional ecological knowledge and laid the groundwork for an assertion of state power over a peopled north.

The origins of this nexus of state power, science, and hunting are described in Greg Gillespie's Hunting for Empire: Narratives of Sport in Rupert's Land, 1840-1870. ${ }^{10}$ Gillespie, who is in the Department of Communications, Popular Culture and Film at Brock University, brings a cultural studies perspective to his analysis of sports hunting narratives. He examines fourteen or fifteen narratives published as the western interior opened to empire, and describes them as assertions of cultural proprietorship of colonial space. Although his concern is with the British Empire, in his final chapter he describes how corporate Canada employed similar literary conventions when the Canadian state extended its own colonial sway over the west.

Gillespie defines his subjects as men who hunted for big game; their numbers include explorers, natural scientists and surveyors as well as men who travelled specifically to hunt. He makes the point that science and hunting were mutually reinforcing activities. Many hunters pursued science as a gentleman's hobby. Upper class sportsmen understood themselves as gentlemen naturalists in pursuit of specimens and trophies rather than meat. They established their scientific credentials by working with eminent British institutions, and employing a scholarly apparatus familiar to many academics, the "footnote façade." many scientists hunted; Gillespie describes John Palliser's expedition, for example, as a "Royal Geographical Society-sanctioned big game hunting expedition." 12

Hunting for Empire is strongest when the focus is upon particular texts and the interplay between hunting, science and imperial power. For example, in Chapter Two, he draws attention to the positivist language used by sportsmen in their prefaces in order to establish narrative authority. The writers repeatedly emphasized that their accounts were firsthand observations, recorded immediately and accurately; Charles Alston Messiter wrote: "I can only say that I have related them [his experiences] exactly as they occurred, exaggerating nothing and taking them from my journals written on the spot." ${ }^{13}$ The truth declarations were frequently paired with self-deprecating remarks. Palliser, for example, noted "In this age of literature, when so many works of imagination are appearing every day, I should despair of such a mere matter-of-fact story finding any place in the attention or interests of the reading world, did I not firmly rely upon your sympathies." ${ }^{14}$ Gillespie describes the tension between positivism and self-deprecation as the "prefatory paradox," and argues it undermines the authority of the hunter's text; the paradox, however, might lie in the subtle way that such British self-deprecation establishes class position, and in that sense reinforces authority.

Most of Gillespie's sportsmen subscribed to a code of hunting ethics 
that distinguished them from the subsistence hunter and established their moral authority. They insisted on 'fair play' and the exercise of skill in the hunt as markers of class status and civilized masculinity. Devices that made the hunt more efficient, such as traps, pits, snares, poisons, or spears, were described as unsporting or cruel. Big game hunter Frederick Ulric Graham, for example, established his own morality and compassion by criticizing the unsporting actions of his guides in 1843: "the half-breeds and Crees ran the last band [of buffalo] and killed three more. I saw the brutes cut up one cow alive-a most cruel operation." ${ }^{15}$ A number of Canadian historians have explored the sportsman's code of ethics; in particular Tina Loo's article, “Of Moose and Men: Hunting for Masculinities in British Columbia, 1880-1939," shows how urban professionals imposed a masculine code of hunting ethics to exclude aboriginal, working class and immigrant pot hunters from the hunt. ${ }^{16}$ Gillespie's contribution is to show how a sportsman's code operated as part of colonial expansion across the western interior. His account might have benefited from closer attention to the particularities of this imperial hunting ethos, and the distinctions between the aristocratic code and subsequent North American middle-class iterations.

Gillespie convincingly draws upon analysis developed by historians of empire, such as David Cannadine and Mary Louise Pratt, to demonstrate how deployment of science in the hunting narratives served the purposes of the British Empire. In Ornamentalism: How the British Saw their Empire, David Cannadine argues that the British empire "was about the familiar and the domestic, as well as the different and exotic: indeed it was in large part about the domestication of the exotic." ${ }^{17}$ Cannadine's argument, made in response to Edward Said's Orientalism, is about social hierarchy, but Gillespie adeptly translates the concept to wildlife and landscape; he argues that, by naming and labeling flora and fauna as well as landscape features, the sportsmen made the foreign familiar. Through a process that Gillespie calls "game associationism," the hunters compared and contrasted North American wildlife with those of Great Britain, and so domesticated the exotic. ${ }^{18}$ He also usefully extends Mary Louise Pratt's notion of anti-conquest to the western interior. Anti-conquest, as he describes it, is the "strategy of cultural representation whereby empire builders sought to demonstrate the innocence of their cultural appropriation while simultaneously underscoring their proprietorship and domination of foreign lands." ${ }^{19}$ Gillespie follows Pratt in showing how the natural sciences, particularly the Linnaean system of classification, assert control through naming and knowing. As big game hunters described the west they inserted the flora and fauna of the north into the European Linnaean system of knowledge about the natural world; in so doing they naturalized their presence on the landscape and brought scientific order to colonial spaces. Despite their apparent innocence of politics, the sports hunting narratives acted to culturally claim the landscape for their British readers.

It is a geographical and temporal leap from Gillespie's narrative to the 
north, but the concept of anti-conquest is one that might fruitfully be applied to the work of wildlife conservation in the north in the twentieth century. Like the Linnaean system of knowledge, the twentieth-century sciences of game management and ecology claimed colonial spaces in the name of the colonizing power. They did so with an apparent innocence, and their complicity with state power becomes evident only when scholars examine the historical record. Kulchyski and Tester, and Sandlos look at a variety of large game animals, but it is the caribou that offers the most telling example of cultural misunderstanding, misguided science, and state coercion. Caribou ecology set the stage for misinterpretation. As Sandlos explains, caribou migrated in large and unpredictable numbers; as a result, when aboriginal hunters intercepted migrating caribou at water crossings, they killed them in ways and numbers that appeared, to outsiders, to be unsporting and wasteful. As Hudson Bay Company chief factor, Roderick MacFarlane reported in the 1860s, "the northern Indians were accustomed ... to slaughter thousands of reindeer annually, chiefly for their skins and tongues, and too often for the sheer love of killing." 20 The selective harvest of hides and tongues made sense in the aboriginal summer economy: the hides were best harvested in August when they were not riddled with warble fly larvae, but in August the flesh, apart from tongues, was too lean to provide good nutrition, and spoiled too rapidly to be preserved. Non-aboriginal observers saw the selective harvesting of hides as wasteful and, over time, "the popular discourse that cast Native hunters as wanton killers of caribou came to permeate the federal government's scientific and ethnological reports on the people and wildlife of northern Canada." ${ }^{21}$

The Northwest Game Act of 1917, brought in at the urging of scientists and explorers, made native hunters subject for the first time to legal sanctions for hunting their main source of subsistence. The law was only occasionally enforced however, until the 1950s, when ongoing fears about a crisis in caribou population reached a crescendo with the reports of wildlife scientists A.W.F. Banfield and John Kelsall. The biologists concluded that the numbers of caribou had dropped from 2.4 million at the turn of the century to 670000 in 1948, and then precipitously to 270569 in 1955 and 200000 in 1957 . Kelsall predicted elimination of the caribou population by 1969 . The numbers caused alarm in the northern administration, particularly when a dramatic photograph of a caribou "slaughter" by Dene at Duck Lake was widely published in the mid 1950s. Migratory caribou populations are notoriously difficult to count, but the evidence gathered in Hunters at the Margin and Kiumajut: (Talking Back) shows that the science was shoddy, and suggest that the CWS actively ignored contradictory evidence in their haste to impose conservation measures. The aboriginal hunters were protected by the Department of Indian Affairs and by provincial officials from the most punitive proposals advanced by the CWS, but concerns about caribou strengthened efforts to radically alter aboriginals' way of life. The northern administration tried to force them to switch to a fishing economy, engaged in forcible resettlement 
schemes to move Inuit from caribou areas, and pressed them into retraining for a modern economy. Sandlos offers the most damning criticism of the bureaucrats; he repeatedly points to examples where their conservationist policies were abandoned when game was to be killed in accordance with the dictates of agricultural society; at various times the ranching of bison or reindeer, the marketing of muskox hair, or the herding of caribou were proposed, in the face of restrictions upon aboriginal hunting. (Though one might ask whether a hunt as tightly controlled as this one was so different from the herding of domestic animals; in her chapter on the caribou crisis in States of Nature, Tina Loo points out that scientific game management of caribou was chosen over reindeer herding because scientific management offered a more efficient way to achieve maximum return, the ecological "carrying capacity," from the land. ${ }^{22}$ )

The caribou crisis offers the most dramatic evidence of the deployment of science by the state and the use of hunting regulations to force aboriginal peoples from their traditional way of life and into modernity; but it was not an anomaly, as the creation of the Thelon Game Sanctuary to protect muskoxen, the exclusion of native hunters from Wood Buffalo National Park, and numerous other examples reveal. Several factors intervened, however, to mitigate the effects of game regulations on aboriginal hunters, at least until the post WWII period. The vast extent of the territories in question and the limited number of officials to enforce regulations meant that aboriginal hunters could usually escape detection. For a long time, "starvation clauses" in the legislation, with the sympathy of local RCMP officers, meant that even those who were caught were not penalized. Aboriginals also resisted; although Sandlos notes that the evidence of this resistance is scant- "the individual voices of northern Aboriginal people on issues of game conservation [are limited] to a very few protest letters and petitions scattered within the voluminous official correspondence on wildlife issues"that their hostility to conservation was unambiguous. ${ }^{23}$ It appears that it was after WWII, with the advent of new technologies, such as surveillance by airplane, that the impact of southern authority was felt widely across the north.

Sandlos' account is exemplary environmental history, politically and culturally engaged and sensitive to wildlife ecology. Kulchyski and Tester are not environmental historians, as the occasional lapse, such as the confusion between carrier pigeons and passenger pigeons, reveals. ${ }^{24}$ They write in the tradition of activist anthropologists like Hugh Brody, and their interest is in the genesis of a political voice among the Inuit. Their strength lies in the capture of the aboriginal voice through oral history, and Part II of their book, "Talking Back," is about the emergence of a rights-based discourse in two specific locations: an Inuit council created at Baker Lake in 1957 and in petitions.

Serge Bouchard provides a fuller picture of the hunter/gatherer way of life in Caribou Hunter: A Song of a Vanished Innu Life, first published in French in 1977, republished in 2004, and translated into English in 2006 by Joan Irving. ${ }^{25}$ 
His account provides a useful counterpoint to histories based upon archival colonial records, which, even if they are read against the grain, rarely provide the aboriginal perspective. Bouchard's "caribou hunter," Mathieu Mestokosho, was an Innu born in about 1885. When interviewed by the young Bouchard in 1971 he still bridled at the criticism of his way of life by outsiders: "the whites still say that the Indians were not good hunters ... [a merchant's wife] complained to the missionary about how lazy Indians were. She claimed that Indians only hunted to survive and as soon as they had what they needed, they took it easy, they slept. But Indians almost never stopped hunting. They had no choice." ${ }^{26}$ The lyrical account reveals Mestokosho's pride in the hunt, the quiet endurance of hardships and dangers, and the sheer drudgery in hauling large amounts of meat through the bush; his voice provides a contrast to the bureaucratic world of game regulation. At times his work quite literally fleshes out the historians' accounts: Sandlos's brief description of the importance of fat in the Inuit diet is given texture here by repeated graphic references to the collection and boiling and eating of fatty bone marrow. He tells the queasy story of four hunters who are forced to eat all the grease from eight caribou in one day, because they have offended the Spirit of the Caribou by wasting food. Like the CWS, Mestokosho blames wasteful hunters for the decline of the caribou, but unlike the CWS he lays blame on white hunters: "We can blame the white hunters for that. They have always hunted like bad Indians. White hunters kill caribou and only take the choice pieces with them... If the caribou are disappearing, it's because white hunters can't stop this waste. The caribou do to them what they do to us. If we're not careful, the caribou will disappear." 27

There are dangers here. Serge Bouchard is fascinated with the aboriginal 'other.' In the preface for the 2004 reissue of his book, he describes his first encounters with Mestokosho: "I was on the threshold of a mental space very different from my own: me the city boy, the Montrealer, the French Canadian ... I had everything to learn, but it was as if I already knew it. This world was as familiar to me as if I had some part of this universe in me." ${ }^{28}$ The romantic notion of a world of hunter gatherers lingering on the frontiers of agricultural society, and lingering at the edges of our cultural memory, has been challenged, most notably by Shepard Krech, who argues that what he calls the "ecological Indian" is a projection of the longings of modernity. ${ }^{29}$ Krech acknowledges that aboriginal peoples may have a special ecological knowledge of the land born of long familiarity, but he takes issue with the idea of the hunter gatherer society as inherently other. ${ }^{30}$ Bouchard's account of Mestokosho's life is seductive, but the very lyricism of the text (which has been translated from Innu, to French, to English) gives pause, and one misses the careful self-conscious parsing of stories of an anthropologist like Julie Cruikshank. ${ }^{31}$

In her preface to the edited collection, The Culture of Hunting, Jean Manore explains that the book originated in a heated discussion between an 
anthropologist and a non-Native hunter. The anthropologist argued in support of aboriginal title, and the special rights of First Nations to hunt and fish, but the hunter insisted that he too "should have the same rights to hunt because hunting was just as integral to his identity as it was to those of First Nations." ${ }^{2}$ The book that resulted from that debate is a useful primer of hunting history in Canada. Burnett's first chapter is reproduced here, as is Gillespie's work on imperialism, and Kulchyski offers a reflective anecdotal piece. Several articles discuss the history of game regulations: Mark Simpson provides an article on sportsman and writer William T. Hornaday; David Calverley describes the genesis of Ontario's game regulations; Manore describes the exclusion of aboriginal and pot hunters from Algonquin Park, and Ken Coates examines the connections between wildlife regulation and aboriginal welfare payments. Swampy-Cree elder Louis Bird (with Roland Bohr) describes the spiritual connection between hunter and prey, and Bruce Hodgins provides an overview of the aboriginal right to hunt.

The more innovative aim, that of establishing the existence of a kind of non-aboriginal hunting identity, is only partially achieved. The book engages with two issues that have politicized Canadian hunters in recent years: federal gun control legislation and the ban on the spring bear hunt. Dale Miner and Simon Wallace weigh in on the merits of gun control and Tim Sopuck and Edward Clark describe the battles with animal rights movements over the spring bear hunt in Ontario and Manitoba. Several contributors try to explain their passion for hunting in terms that non-hunters can understand. Edward Clark argues that hunting is spiritual at its base. It is more than recreation, he argues, it is a way of knowing the natural world and a way of reconnecting with a past way of being in the world. Clark argues that non-aboriginal hunters "feel every bit as knowledgeable about, involved with, passionate about and respectful of the game we pursue." ${ }^{33}$ Leigh Clarke makes the point that hunters have a special ecological knowledge: "the poorest hunter is more aware of nature than many people who enjoy it mainly for its scenery and clean air." ${ }^{34}$ Robert Sopuck notes that hunters support conservation movements. This reader — an urban academic, and a woman-followed their arguments up to this point. (Although it seems important to note that aboriginal hunting rights spring from aboriginals' history and legal status, rather than their relationship to the animals they hunt.) But then Jason E. McCutcheon, a young hunter, describes the killing of his first grizzly. When the bear runs away with three shots in him, to be brought down with a final well-aimed shot, my sympathy with the hunter collapsed. Many of the defenses of hunting, here and elsewhere, avoid graphic descriptions of the moment of the kill. Kulchyski, for example, nostalgically recalls the meditative waiting, the sense of community, and the ecological knowledge required for a successful hunt, all elements likely to gain the sympathy of any nature lover. It is to their credit that the editors of this volume have included McCutcheon's description of this moment, and my reaction perhaps a measure of the divide between hunters and others that they are trying to cross. 
The decision to focus on the killing of the grizzly — the animal highest in the hierarchy of big game animals and one of the animals most likely to elicit a sympathetic response-brings us back to our original question: why do the histories considered here focus on the hunting and conservation of big charismatic game animals - the muskoxen, caribou, bison and bear? Why have we allowed the preoccupations of a particular class of hunters to dominate the history of the hunt, and more broadly, the history of relations with wild animals? Lance van Sittert has argued, from his position as a South African, that we have allowed an imperial ethos of hunting and conservation to unduly shape colonial history: "the history of wild animals in southern Africa has been written from the elite archives of imperial hunters and administrators and has elevated their particular concern with the preservation of a small minority of 'game' animals in 'reserves' into a grand theory." ${ }^{35}$ In Canada George Colpitts' Game in the Garden has made some steps in moving beyond this elite archive. By paying close attention to the regional history of the west he dislodges the recreational hunter (at least until after the World War I) and places new emphasis on the provision of meat; he moves our gaze from Tina Loo's trophy-laden den to the meat wagon, dripping with blood and flesh.

One might further destabilize this masculine history of big game hunting by asking what a history of hunting would look like if women were included. For women do hunt, and always have. Lisa Szabo points out that Grace Thompson Seton and Agnes Deans Cameron wrote about big game hunting in sportswoman narratives that parallel Gillespie's tales, and women also hunted in more ordinary ways: in 1963 the Canadian Wildlife Service reported that 41000 women hunted or fished. ${ }^{36}$ Aboriginal women's hunting was essential. Sarah Carter has observed that when the bison disappeared it was the women's ability to trap the gophers, rabbits and small game of the prairie that staved off starvation on prairie reserves. ${ }^{37}$ In 1971 Mestokosho recalled: "when their husbands were out hunting big game, it was also hunting season for women, because they did more than just hunt for rabbits. They put out traps for marten. They killed a lot of animals and brought back good food." ${ }^{38}$

Little has been written about women's participation in the big game hunt. Tina Loo dissects the masculinity of sportshunting nicely in "Moose and Men," but she gives only passing reference to women, noting that they were met with mockery or condescension. Much more might be done. How did women themselves understand their participation? Can we detect in some of the photographs of women hunters a delight in the performance of a heightened masculinity? Kulchyski describes aboriginal women who take on the male hunting role and at the same time are seen to adopt a male nature, and he concludes that "perhaps the activities of certain women hunters destabilize more than questions around the gendered division of labour." ${ }^{39}$ The heated reactions women hunters provoked among their male peers suggest that gender was most unstable where it was most 
visible.

It was not only the hunt that was gendered. Wildlife conservation movements were also gendered, as Sarah Watts' discussion of Theodore Roosevelt in Rough Rider in the White House: Theodore Roosevelt and the Politics of Desire reveals. Her analysis shows that the manly intersection of sportsmanship and conservation is a rich area for investigation. ${ }^{40}$ Burnett's brief reference to the difficulties faced by women entering the Canadian Wildlife Service (the first woman biologist joined only in 1966 and women were only fully accepted in service in the 1980s), suggests that this masculinity carried over into scientific wildlife management in the post WWII years. The technology and science of the postwar Canadian Wildlife Service might be understood as a northern extension of the modernist project described in Chris Dummitt's The Manly Modern: Masculinity in Postwar Canada. ${ }^{41}$

But more important than further analysis of masculinities, the wider perspective gained by the inclusion of women hunters might alter our conception of the hunt. In his contribution to The Culture of Hunting, Kulchynski makes the intriguing point that feminising the hunt, disentangling hunting from masculinity, could disconnect it from the idea of a "murderous orgy." Andrea L. Smalley argues that women hunters have already been deployed in this fashion; late nineteenth century hunting journals featured women hunters as part of a campaign to differentiate sportshunting from pot hunting. Women were disappeared and the hunt was masculinised again once this objective was achieved. ${ }^{43}$ Beyond the politics of sports hunting, however, it appears that women hunted differently; for one thing they hunted different animals. The women referred to by Mestokosho hunted the smaller mammals, and the CWS survey showed more women preferred small game in 1963. ${ }^{44}$ The pursuit and slaughter of these animals was a very different activity than the heroic big game hunt. In 1859, the Earl of Southesk, one of Gillespie's sportsmen, looking over the dozens of animals he had shot at Jasper House, wrote: "One thinks little — too little of the killing of small game, but in shooting large game the butchery of the act comes more home, one sees with such vividness the wounds, and the fear, and the suffering." ${ }^{\prime 5}$ It could be that the historical emphasis on the big game hunt, the focus on the masculine slaughter (or protection) of charismatic megafauna, has played a role in producing the social attitudes that hunters today are trying so hard to overcome.

\section{NOTES}

1 Tina Loo, States of Nature: Conserving Canada's Wildlife in the Twentieth Century (Vancouver: University of British Columbia Press, 2006); J. Alexander Burnett, Passion for Wildlife: The History of the Canadian Wildlife Service (Vancouver: University of British Columbia Press, 2003); Greg Colpitts, Game in the Garden: A Human History of Wildlife in Western Canada to 1940 (Vancouver: University of British Columbia Press, 2002); Lyle Dick, Muskox Land: Ellesmere Island in the Age of Contact (Calgary: University of 
Calgary Press, 2001), and Hans M. Carlson, Home is the Hunter: The James Bay Cree and Their Land (Vancouver: University of British Columbia Press, forthcoming in September, 2008). Dissertations on wildlife conservation include Roland Bohr, "Continuity and Change in Historic Indigenous Hunting and Military Technology on the Northern Great Plains and in the Eastern Subarctic," (Ph.D. diss., University of Manitoba, 2005); Darcy Ingram, "Nature's Improvement: Wildlife, Conservation, and Conflict in Quebec, 1850-1914," (Ph.D. diss., McGill University, 2007) and Darin Kinsey, "Fashioning a Freshwater Eden: Elite Anglers, Fish Culture, and State Development of Quebec's Sport Fishery (Ph.D. diss., Université du Québec à TroisRivières, 2008).

2 For a paper see Jonathan Peyton, University of British Columbia, "Imbricated Geographies of Conservation and Consumption in the Stikine Plateau," presented at the Canadian Historical Association Annual Meeting, June 2008, University of British Columbia and available online at Network in Canadian History and Environment website at www.niche.uwo.ca/node/392 (accessed September 3, 2008).

3 Janet Foster, Working for Wildlife: The Beginning of Preservation in Canada, second edition, with an introduction and afterword with Lorne Hammond (Toronto: University of Toronto Press, 1978; 1998).

4 Burnett, 178.

5 Burnett, 169.

6 Burnett, 110.

7 Peter Kulchyski and Frank James Tester, Kiumajut (Talking Back): Game Management and Inuit Rights, 1900-70 (Vancouver: University of British Columbia Press, 2007), 274.

8 Kulchyski and Tester, 274, 12. The book focuses upon "the way in which Enlightenment logic expresses itself in and through those who took up the challenge of scientifically managing game in the period in question". Kulchyski and Tester, 13.

9 John Sandlos, Hunters at the Margin: Native People and Wildlife Conservation in the Northwest Territories (Vancouver: University of British Columbia Press, 2007), 237.

10 Greg Gillespie, Hunting for Empire: Narratives of Sport in Rupert's Land, 1840-1870 (Vancouver: University of British Columbia Press, 2007).

11 Gillespie, 32.

12 Gillespie, 4.

13 Gillespie, 19.

14 Gillespie, 23.

15 Gillespie, 38.

16 Tina Loo, "Of Moose and Men: Hunting for Masculinities in British Columbia, 18801930," The Western Historical Quarterly 32, no. 3 (Autumn, 2001). See also George Colpitts, Game in the Garden, Chapter Three. For the use of the code to exclude aboriginal hunters from the park at Banff, see Theodore (Ted) Binnema and Melanie Niemi, "Let the Line Now Be Drawn: Wilderness, Conservation, and the Exclusion of Aboriginal People from Banff National Park in Canada," Environmental History 11, no. 4 (October 2006): 724-750. Nancy B. Bouchier and Ken Cruikshank place the conflict between sportshunter and pothunter at the heart of their article, "Sportsmen and Pothunters': Environment, Conservation, and Class in the Fishery of Hamilton Harbour, 1858-1914," Sport History Review 28 (1997): 1-18.

17 Cannadine, xix. Cited in Graeme Wynn, "Foreword," xix.

18 Gillespie, 74. 
19 Gillespie, 72.

20 Sandlos, 152.

21 Sandlos, 151.

22 Loo, States of Nature, 137-138.

23 Sandlos, 16. The lack of evidence forces him to speculate about their response. For example: "although the available archival evidence contains few traces of Aboriginal voices from the period, one incident suggests that Native hunters actively resisted ...". Sandlos, 158; and "the kill may have constituted a protest...". Sandlos, 217.

24 Kulchyski and Tester, 24.

25 Serge Bouchard, Caribou Hunter: A Song of a Vanished Innu Life trans. Joan Irving (Montreal: Les Éditions Boréal, 2006).

26 Bouchard, 130.

27 Bouchard, 171.

28 Bouchard, 15. Kulchyski and Tester also refer to the "call of the other." Kulchyski and Tester, 249. Kulchyski acknowledges the importance of Brody's work in his contribution to Jean L. Manore and Dale Miner, eds, The Culture of Hunting (Vancouver: University of British Columbia Press, 2002), 29. Brody's most recent expression of this sense of the otherness of the hunter gatherer is in his The Other Side of Eden: Hunters, Farmers and the Shaping of the World (Northpoint Press, 2001).

29 Shepard Krech, The Ecological Indian: Myth and History (New York: Norton, 1999).

30 For Shepherd Krech's acknowledgement of traditional ecological knowledge, see, "Reflections on Conservation, Sustainability, and Environmentalism in Indigenous North America," American Anthropologist 107, no. 1: 78-86.

31 Julie Cruikshank in collaboration with Angela Sidney, Kitty Smith and Annie Ned, Life Lived Like a Story: Life Stories of Three Yukon Elders (Lincoln: University of Nebraska Press, 1990) and Do Glaciers Listen? Local Knowledge, Colonial Encounters and Social Imagination (Vancouver: University of British Columbia Press, 2005). In marked contrast to Cruikshank, who made her sources co-authors, Mestokosho's identity has been completely erased from the title page of the English edition of Caribou Hunter. The title pages attribute the text to Bouchard, the translation to Joan Irving, and the foreword to J. Edward Chamberlain, but make no reference to Mestokosho. The earlier French edition at least includes his name in the title: Récits de Matheiu Mestokosho: chas seur Innu.

32 Jean L. Manore and Dale Miner, eds., The Culture of Hunting (Vancouver: University of British Columbia Press, 2007).

33 Manore and Miner, 206.

34 Manore and Miner, 13.

35 See Lance van Sittert, "Commodification of Wild Animals in the Cape Colony/Province c. 1850-1950," Journal of African History 46 (2005): 269-291.

36 Lisa Szabo, "Sticking to her Guns: A History of Women Hunters," unpublished paper, in the author's possession. Szabo cites Grace Thompson Seton, A Woman Tenderfoot (1900); Agnes Deans Cameron, The New North: Being Some Accounts of a Woman's Journey Through Canada to the Arctic (1912), and Canadian Wildlife Service, Preferences, Purchases, Participants, Prevalence, People, You: Fishing and Hunting in Canada, 1961 (1963).

37 Sarah Carter, "First Nations Women and Colonization on the Canadian Prairies, 1870s-1920s," in Rethinking Canada: The Promise of Women's History, 4th ed., eds. 
Veronica Strong-Boag et al., (Don Mills: Oxford University Press, 2002), 135-148.

38 Bouchard, 142.

39 Manore and Miner, 33.

40 Sarah Watts, Rough Rider in the White House: Theodore Roosevelt and the Politics of Desire (Chicago: University of Chicago Press, 2003).

41 Burnett, 255. Christopher Dummitt, The Manly Modern: Masculinity in Postwar Canada (Vancouver: University of British Columbia Press, 2007). Consider as well Tina Loo's list of conservationists: Jack Miner, Charles Elton, Grey Owl, Farley Mowat, and Bill Mason.

42 Manore and Miner, 32.

43 Andrea L. Smalley, "'Our Lady Sportsman': Gender, Class and Conservation in Sport Hunting Magazines, 1873-1920," Journal of the Gilded Age and Progressive Era 4, 4 (October 2005): 355-380.

44 Among women hunters, 23350 preferred small game compared to the 16770 preferring big game.

45 The Earl of Southesk, Saskatchewan and the Rocky Mountains (Edinburgh: Edmonston and Douglas, 1874), 216-217. Cited in Colpitts, 8. 